\title{
Sekuritisasi Illegal, Unreported, Unregulated Fishing (IUUF) di Perairan Indonesia di Era Pemerintahan Joko Widodo
}

\author{
M. Rizqi Isnurhadi \\ Universitas Gadjah Mada
}

\begin{abstract}
Abstrak
Perairan Indonesia yang luas menyajikan peluang dan tantangan. Di satu sisi, ia menyajikan berbagai sumber daya. Namun, di sisi lain, Indonesia menghadapi tantangan untuk menjaganya dari potensi ancaman. Salah satu tantangan terbesar bagi Indonesia adalah menjaga teritori perairannya dari aktivitas penangkapan ikan yang illegal, tidak dilaporkan dan tidak diatur (Illegal, Unreported and Unregulated Fishing (IUUF)). Maraknya aktivitas ini mengancam kelangsungan hidup industri perikanan Indonesia. Oleh karena itu, untuk mendukung agenda Poros Maritim Presiden Joko Widodo, usaha untuk melawan ancaman ini harus dijadikan prioritas utama. Penulis menggunakan kerangka keamanan oleh Buzan dkk, di mana isu keamanan tidak hanya terbatas pada isu keamanan tradisional, tetapi juga bagaimana ia disajikan sebagai ancaman eksistensial (existential threats). Tulisan ini bertujuan untuk mengevaluasi proses sekuritisasi kegiatan IUUF di perairan Indonesia di masa pemerintahan Presiden Joko Widodo. Tulisan ini juga membahas elemen speech act sebagai securitizing move melalui pengumpulan pidato/publikasi pemerintah Indonesia, khususnya Kementrian Kelautan dan Perikanan, serta menganalisis apakah securitizing move yang telah dilakukan efektif dalam mencapai targetnya.
\end{abstract}

Kata-kata kunci: sekuritisasi, penangkapan ikan illegal, keamanan kelautan, Indonesia

Indonesian waters present both opportunities and challenges for the country. On one hand, it provides Indonesia with various resources to explore. On the other hand, Indonesia faces the challenges to guard it against potential threats. One of the biggest challenges that Indonesia faces is guarding its waters against Illegal, Unreported and Unregulated Fishing (IUUF). The widespread of IUUF activities had certainly threatens the survivability of Indonesian fishing industries. Therefore, along with President Joko Widodo's administration main agenda of Maritime Fulcrum, the threat needs to be addressed as a top priority. This paper uses Buzan et al. framework of security, where security issues are not limited to traditional security issues, but also contingent on how it is presented as an existential threat. Thus, this paper aims to examine the securitization process of IUUF activities in Indonesian waters during Joko Widodo's administration. This paper also discusses the element of speech act as securitizing moves by gathering speeches/publications published by Indonesia's government officials, specifically the Ministry of Maritime Affairs and Fisheries. This paper will then seek to analyze whether the securitizing move was effectively done to influence its target audience or not.

Keywords: securitization, illegal fishing, maritime security, Indonesia 


\section{Pendahuluan}

Indonesia merupakan dengan potensi kekayaan sumber daya alam yang melimpah, terutama dalam bidang maritim. Hal tersebut dikarenakan sebagian besar dari teritori Indonesia berupa perairan. Berdasarkan informasi yang dikumpulkan oleh Badan Informasi Geospasial (BIG), luas garis pantai Indonesia mencapai sepanjang 99.093 kilometer (Samantha 2013). Indonesia memiliki batas laut yang luas terutama pasca pengusungan Wawasan Nusantara melalui Deklarasi Djuanda yang mendeklarasikan bahwa lebar laut wilayah Indonesia adalah 12 mil. Perairan kepulauan dikelilingi oleh garis pangkal yang menghubungkannya dengan titik-titik terluar dari Pulau Terluar Indonesia. Luas laut kepulauan Indonesia telah diterima di dalam UNCLOS 1982. Luas perairan Indonesia ini kemudian memunculkan peluang serta tantangan sekaligus. Di satu sisi, Indonesia mendapatkan kekayaan laut yang melimpah. Kekayaan sumber daya alam di perairan tersebut memberikan kesempatan bagi Indonesia untuk mendapatkan keuntungan besar. Selain itu, perairan Indonesia mengandung berbagai sumber daya alam, seperti berbagai jenis ikan. Hal tersebut menjadikan mayoritas masyarakat yang tinggal di pesisir pantai Indonesia mencari penghidupan melalui laut sebagai nelayan.

Namun, di sisi lain, Indonesia harus mengelola perairannya dengan baik agar dapat memaksimalkan potensinya. Sayangnya, kekayaan laut Indonesia tidak dapat mencapai potensi maksimumnya untuk menyejahterakan para nelayan. Salah satu penghambat upaya optimalisasi potensi kelautan adalah maraknya kegiatan penangkapan ikan secara ilegal, tidak dilaporkan, dan tidak diatur (Illegal, Unreported and Unregulated Fishing). Menurut Kementerian Kelautan dan Perikanan (KKP), pencurian ikan telah merugikan Indonesia sebanyak 20 juta dollar AS setiap tahunnya. Selain itu, aktivitas penangkapan ikan illegal juga dapat merusak ekosistem laut dan memengaruhi keberlanjutan potensi tangkapan ikan di Indonesia. Dilansir dari Kompas.com (2017), keberadaan kapalkapal asing tanpa izin yang terus mencuri dan mengeksploitasi perairan Indonesia dapat mengakibatkan overfishing.

Beberapa contohnya adalah adanya eksploitasi berlebihan di Laut Aru, Laut Arafura, dan Laut Timur terhadap ikan tuna, cakalang, tongkol, kembung, cumi-cumi, udang, lobster, kepiting, dan 
rajungan. Kemudian ada pula eksploitasi di Laut Jawa terhadap ikan tuna, lobster, dan cumi-cumi. Kegiatan tersebut dapat berakibat pada anjloknya potensi tangkapan ikan di perairan Indonesia. Menurut kajian UCSB dan Balitbang Kelautan dan Perikanan, jika eksploitasi terus terjadi, maka biomassa ikan di perairan nusantara akan anjlok hingga 81 persen pada tahun 2035 (Marta 2017). Menanggapi hal tersebut, salah satu upaya terbaru yang dilakukan oleh pemerintah Indonesia di era pemerintahan Presiden Jokowi adalah dengan kebijakan menenggelamkan kapal. Kebijakan tersebut diberlakukan kepada kapal-kapal yang tertangkap melakukan illegal fishing di perairan Indonesia. Sebenarnya, dasar hukum bagi kebijakan tersebut telah dirumuskan sejak tahun 2009. Menurut Pasal 69 Ayat (4) Undang-Undang Nomor 45 Tahun 2009, dalam melaksanakan fungsinya, penyidik dan/atau pengawas perikanan dapat melakukan tindakan khusus berupa pembakaran dan/atau penenggelaman kapal perikanan yang berbendera asing berdasarkan bukti permulaan yang cukup (Pasopati 2015). Tetapi dari segi jumlah yang dieksekusi, dalam kurun waktu 2009-2012, hanya sejumlah 37 kapal yang ditenggelamkan (detikFinance 2014).

Sementara itu, sejak Joko Widodo terpilih sebagai presiden pada tahun 2014 dan ditunjuknya Susi Pudjiastuti sebagai Menteri Kelautan dan Perikanan, sejumlah 151 kapal sudah ditenggelamkan (DH 2016). Tujuannya adalah meningkatkan efek jera bagi kapalkapal asing yang melakukan illegal fishing. Strategi penenggelaman kapal ini didukung dengan pembentukan Satuan Tugas Pemberantasan Penangkapan Ikan secara Ilegal (Satgas 115) yang disahkan oleh Presiden Joko Widodo melalui Perpres No. 115 tahun 2015. Satgas 115 merupakan penyelenggara penegakan hukum satu atap (one roof enforcement system), yang terdiri dari elemen TNI AL, Polri, BAKAMLA, dan Kejaksaan Republik Indonesia, sehingga memudahkan koordinasi, mendorong sinergi, dan melaksanakan fungsi fasilitasi dalam memberantas illegal fishing (Marta 2017).

Kebijakan penenggelaman bukanlah solusi akhir yang ditawarkan pemerintah Indonesia. Hal tersebut merupakan bagian dari suatu strategi besar yang dijalankan oleh Kementerian Kelautan dan Perikanan untuk mencegah pencurian ikan di perairan Indonesia. Alternatif kebijakan lain juga dijalankan, diantaranya adalah Peraturan Menteri KKP tentang moratorium penerbitan lisensi bagi kapal nelayan asing selama enam bulan. Kemudian ada 
pula Peraturan Menteri KKP No. 57 Tahun 2014 yang melarang transhipment atau jual-beli ikan di tengah lautan (Indra 2016). Selain itu, terdapat Perpres 44/2016 tentang daftar negatif investasi asing yang menyatakan bahwa usaha penangkapan ikan tertutup untuk asing (Marta 2017). Kini pemerintah Indonesia mulai aktif dalam menjalin kerjasama dengan beberapa negara, seperti Sri Lanka (Wardani 2017), Australia (KKP News 2016), Russia (KKP News 2016), dan Norwegia (KKP News 2017) demi membantu pemberantasan aktivitas illegal fishing. Langkah-langkah pemerintah tersebut dapat dinilai sebagai perwujudan keseriusan Presiden Joko Widodo dalam menangani isu Illegal, Unreported and Unregulated Fishing (IUUF). Oleh karena itu, tulisan ini akan membahas (1) proses sekuritisasi isu IUUF di perairan Indonesia berjalan di era Presiden Joko Widodo; dan (2) faktor yang memengaruhi keberhasilan ataupun ketidakberhasilan sekuritisasi isu IUUF tersebut.

\section{Mendefinisikan Keamanan}

Walt (1991) memaparkan bahwa studi keamanan adalah studi fenomena perang. Perspektif keamanan tradisional fokus pada definisi keamanan dengan negara sebagai referent object dan mengesampingkan keberadaan referent object selain negara. Perdebatan mengenai definisi isu keamanan masih berlanjut, karena terdapat ilmuwan yang berargumen bahwa isu keamanan harus dibatasi pada isu keamanan tradisional dengan referent object pada negara dan ada ilmuwan yang ingin melebarkan isu-isu keamanan (Buzan et. al. 1997). Buzan et. al. (1997) beragumen bahwa definisi keamanan tradisional terlalu sempit dan memandang sektor-sektor lain yang seharusnya dipertimbangkan, antara lain politik, ekonomi, sosial, lingkungan, dan militer. Menurut Buzan et. al. (1998), suatu isu dapat menjadi isu keamanan ketika isu tersebut terkait dengan hal yang mengancam (existential threats) suatu referent object-yang tidak terbatas pada negara, tetapi juga masyarakat. Ketika suatu isu menjadi isu keamanan, ia menjadi justifikasi untuk mengambil langkah-langkah luar biasa dan darurat, seperti memobilisasi kekerasan untuk menanganinya. Secara teoritis, isu publik berada dalam spektrum berikut ini: 
Gambar 1. Skema Sekuritisasi

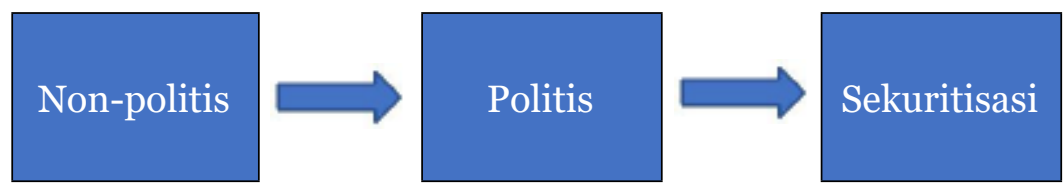

Adapun isu non-politik adalah ketika negara tidak melakukan apapun terhadapnya. Selanjutnya, isu akan menjadi isu politik apabila mengalami politisasi, menjadi bagian perdebatan publik, dan melibatkan keputusan pemerintah. Sekuritisasi adalah langkah untuk mengangkat isu politis menjadi isu sekuriti. Suatu isu disekuritisasi melalui langkah securitizing move yang dilakukan dengan speech act. Speech act sendiri tidak menjamin bahwa isu tersebut otomatis menjadi isu sekuriti. Menurut Buzan et. al. (1998), keberhasilan speech act sendiri tergantung pada prasyarat (facilitating condition) yang dapat dikategorikan menjadi dua hal yaitu, (1) internal, melalui penggunaan tata bahasa dan struktur linguistik-nya; dan (2) eksternal, yang mencakup modal sosial dari aktor yang melakukan sekuritisasi serta fitur dari ancaman yang disekuritisasi. Jika prasyarat-prasyarat tersebut terpenuhi, maka langkah securitizing move akan lebih mudah.

Sekuritisasi bukan sekedar menyajikan isu tertentu sebagai hal yang mengancam. Akan tetapi, suatu hal dapat menjadi isu keamanan hanya ketika audiens menerimanya. Sekuritisasi, menurut Buzan et. al. (1998), terjadi ketika ada ancaman eksistentsial, terdapat aksi serius (emergency conditions), dan audiens melegitimasi pelanggaran peraturan dalam menanganinya. Floyd (2016) menambahkan bahwa sekuritisasi hanya dapat dikatakan sukses ketika terdapat identifikasi ancaman sehingga mengundang respons (securitizing move) yang diikuti oleh adanya perubahan perilaku oleh aktor yang relevan serta adanya justifikasi oleh securitizing actor dengan referensi terhadap ancaman yang ia deklarasikan melalui securitizing move.

\section{Identifikasi Speech Act}

Salah satu aktor yang melakukan securitizing move dalam kasus IUUF adalah Kementerian Kelautan dan Perikanan Indonesia. Speech act dapat diidentifikasi dari publikasi-publikasi Kementerian Kelautan dan Perikanan Indonesia. Kementerian Kelautan dan Perikanan 
Indonesia mengusung tiga tema penting dalam visi dan misinya, yakni kedaulatan, keberlanjutan dan kesejahteraan. Sedangkan pada aspek kebijakan pencegahan dan pemberantasan, IUUF ditempatkan di tema besar Kedaulatan. Dalam visinya tertulis:

"Membangun kedaulatan yang mampu menopang kemandirian ekonomi dalam pengelolaan sumber daya kelautan dan perikanan. Kesadaran untuk menegakkan kedaulatan maritim harus tumbuh dalam diri setiap manusia Indonesia. Kedaulatan dimulai dari keberanian dan ketegasan serta sikap konsisten dalam penegakkan hukum dengan sanksi yang tegas dan adil."

Di laman tersebut juga dipaparkan kerugian Indonesia akibat IUUF:

"IUU Fishing sangat merugikan Indonesia. Kedaulatan, keberlanjutan, dan pengelolaan SDKP, serta stabilitas politik kita terganggu. IUUF juga merugikan negara \pm USD 20 juta pertahun, disamping memicu timbulnya berbagai tindak pidana terorganisir."

Menteri Susi Pudjiastuti pun dalam berbagai kesempatan menyampaikan pidato yang dapat diidentifikasi sebagai suatu speech act. Dalam kesempatan serah terima jabatan (detikFinance 2014), ia menyatakan:

"Pak Cicip yang saya hormati, saya mengambil pekerjaan ini tidak untuk kaya dan menjadikan saya hebat. Saya terima pekerjaan ini karena pengalaman 33 tahun saya di sektor perikanan dan 10 tahun di penerbangan bisa membantu Indonesia menjadi lebih baik. Menjadi tuan rumah di negeri sendiri, membangun ekonomi mandiri, dan membangun kebanggaan diri sendiri. Jangan sampai laut kita yang besarnya $70 \%$ atau 5 kali dari Thailand dan beribu-ribu kali lipat dengan Malaysia, tetapi angka ekspor kita kalah jauh dibandingkan Malaysia dan Thailand. Ini jadi target kita semua."

Wiji (2017) mengungkapkan bahwa di kesempatan lainnya, yakni saat melantik Eko Djalmo Asmadi sebagai Dirjen Pengawasan Sumber Daya Kelautan dan Perikanan (PSDKP) di Ballroom Gedung Mina Bahari III kantor KKP, Jakarta, Jumat (20/1) “Menjaga laut kita sangat penting, Indonesia telah tumbuh perikanannya dan tertinggi dalam sejarah. Kita telah mengembalikan neraca perdagangan yang tadinya paling rendah di ASEAN sekarang 
makin tinggi. Ini sudah benar dan harus diteruskan". Dikutip dari Kompas, Menteri Susi menyebut Illegal Fishing sebagai musuh negara: "Kita berencana untuk kerja sama, bahwa para pelaku illegal fishing adalah musuh negara. Mereka bukan mewakili negara, tapi mewakili kejahatan" (Movanita 2016). Di kesempatan lain, Menteri Susi bahkan menyebutkan bahwa Illegal Fishing sebagai musuh dunia, "Penangkapan ikan ilegal itu sangat serius. 'IUU fishing' bukan hanya musuh Indonesia melainkan 'global international enemy' (musuh dunia internasional) dan semua negara setuju ini harus diberantas" (Burhani 2015).

Selain berbicara kepada audiens dalam negeri, Kementerian Kelautan dan Perikanan juga berupaya melakukan sekuritisasi isu IUUF di tingkat internasional. Dalam kesempatan saat berbicara di konferensi kelautan PBB: Transnational Organized Crime in Fisheries Industry bersama Norwegia, Interpol dan United Nations Office on Drugs and Crime (UNODC), menteri Susi Pudjiastuti meminta agar PBB menetapkan praktik Illegal Fishing sebagai kejahatan transnasional yang terorganisir.

\begin{abstract}
"Kita harus mengakui bahwa Illegal Unreported and Unregulated (IUU) Fishing ini terkait dengan kejahatan transnasional yang terorganisir. Operasinya sering didukung oleh kelompok terorganisir. Indonesia adalah saksi pelanggaran hak asasi manusia, mulai dari perdagangan manusia, perbudakan anak, hingga pelecehan fisik dan seksual yang terjadi di kapal penangkap ikan. Tak jarang juga terjadi penyelundupan mulai dari bahan makanan seperti beras, bawang, pakaian, hingga obat-obatan terlarang, alkohol, dan narkotika. Mereka juga menyelundupkan satwa liar yang terancam punah, seperti burung beo, burung surga, dan armadillo," (KKP News, 2017)
\end{abstract}

Speech act para pejabat pemerintah Indonesia tersebut ditujukan agar mendorong masyarakat Indonesia untuk memberikan legitimasi bagi pemerintah untuk melakukan kebijakan publik yang sesuai untuk menangani isu illegal fishing. Diantaranya adalah kebijakan menenggelamkan kapal asing yang menangkap ikan secara illegal di perairan Indonesia dan didukung pula dengan pembentukan Satgas 115 (Marta 2017). Keberhasilan suatu securitizing move adalah ketika audiens terpengaruh dengan speech act yang dilakukan sehingga menerima bahwa isu yang mengalami sekuritisasi adalah isu yang 
menimbulkan existential threats serta melegitimasi penggunaan metode-metode luar biasa dalam menangani isu tersebut (Buzan et. al. 1998). Menteri Susi Pudjiastuti sendiri mengakui bahwa respons dan partisipasi dari masyarakat merupakan elemen penting dalam kesuksesan pemberantasan illegal fishing (KKP News 2015).

Tanggapan masyarakat ataupun opini publik terhadap suatu isu dapat dilihat dari perilaku media dalam membingkai isu tersebut dalam pemberitaannya. Berdasarkan kutipan artikel di KKP News, Sekretaris Himpunan Nelayan Seluruh Indonesia (HNSI) Sumatera Utara, Pendi Pohan menyatakan: "HNSI sangat mendukung dikeluarkannya Perpres IUU Fishing itu, supaya pencurian ikan betul-betul bisa diberantas" (Winata 2015). Dukungan dari HNSI terhadap Perpres IUU Fishing menunjukkan bahwa respon darurat diperlukan dalam menangani isu tersebut. Sementara itu, di Kupang, nelayan telah melakukan sumpah adat untuk tidak terlibat dalam melakukan illegal fishing. (KKP News 2015). Tanggapan positif dari para nelayan menunjukkan bahwa securitizing move yang dilakukan sampai pada audiens yang ditargetkan oleh securitizing actor, yakni Kementerian Kelautan dan Perikanan.

\section{Penanganan Isu IUUF setelah Sekuritisasi}

Metode utama yang digunakan pemerintahan Presiden Joko Widodo adalah penenggelaman kapal. Tercatat ada 151 kapal telah ditenggelamkan (DH 2016), meningkat jauh dari yang ditenggelamkan pada periode sebelumnya yakni 37 kapal pada 2009-2012. Selain itu, kebijakan penenggelaman kapal di era Joko Widodo didukung dengan pembentukan Satgas 115, penyelenggara penegakan satu atap dengan elemen TNI AL, Polrim BAKAMLA, dan Kejaksaan Republik Indonesia (Marta 2017). Menurut Floyd (2016), suatu kondisi dapat disebut securitized tidak hanya ketika terjadi penangguhan aturan hukum tetapi merupakan situasi ketika (1) diluluskannya peraturan baru; (2) diberikannya kekuasaan darurat kepada suatu aktor; atau (3) saat apparatus keamanan negara atau legislasi darurat digunakan untuk menangani isu yang sebelumnya tidak ia tangani. Kebijakan yang dilaksanakan oleh pemerintah Presiden Joko Widodo dapat dikategorikan sebagai kebijakan luar biasa.

Seharusnya, dalam situasi normal, kegiatan IUUF merupakan 
suatu aksi kriminal biasa. Layaknya suatu aksi kriminal, pengenaan hukuman harus melalui suatu prosedur hukum. Contohnya, pihak tergugat dan penggugat harus mencantumkan bukti sehingga tidak ada keraguan dalam kasus legalnya. Dengan melaksanakan pembakaran kapal sesuai Pasal 69 Ayat (4) Undang-Undang Nomor 45 Tahun 2009, prosedur hukum dapat dilewati, penyidik dan/atau pengawas perikanan dapat melakukan tindakan khusus berupa pembakaran dan/atau penenggelaman kapal perikanan yang berbendera asing berdasarkan bukti permulaan yang cukup saja (Pasopati 2015). Selain itu, pembentukan Satgas 115 yang merupakan penyelenggara penegak hukum satu atap (one roof enforcement system) dapat dianggap sebagai suatu metode penanganan yang luar biasa. Sebelum digunakan dalam kasus penanganan IUUF, Satgas serupa pernah dibentuk dalam upaya memudahkan penegakan hukum dalam isu lingkungan hidup (Tempo 2003). Satgas yang menggabungkan kejaksaan dan kepolisian tersebut dibentuk untuk memudahkan pengelolaan isu lingkungan hidup. Pembentukan Satgas 115 untuk menangani penangkapan ilegal dapat dikatakan suatu penyetaraan antara isu penangkapan ikan illegal dengan isu lingkungan hidup. Pembentukan Satgas 115 sebagai metode penanganan isu IUUF menunjukkan adanya peraturan baru yang memberikan kekuasaan darurat kepada Satgas 115. Satgas 115 juga merupakan badan yang mengumpulkan aparatus-aparatus negara untuk menangani isu yang sebelumnya tidak tertangani.

Gambar 2. Skema Sekuritisasi IUUF di Indonesia
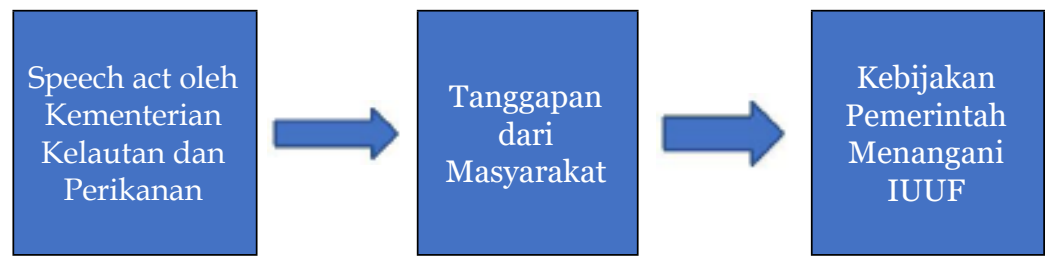

\section{Agenda Keamanan Ekonomi}

Buzan et. al. (1998), dalam buku Security: A New Framework of Analysis, memaparkan bahwa sekuritisasi di sektor ekonomi sangat terkait dengan nasionalisme ekonomi. Keamanan ekonomi mencakup berbagai referent object, termasuk individu, kelas, negara, dan sistem pasar global. Dalam kasus IUUF, sektor yang disekuritisasi adalah sektor ekonomi. Narasi-narasi yang dibangun dari speech 
act yang dilakukan menekankan pada kerugian ekonomi. Dalam misi Kementerian Kelautan dan Perikanan ditekankan bahwa Illegal Fishing telah merugikan Indonesia sebanyak kurang lebih dua puluh juta dollar Amerika Serikat per tahun. Dari pernyataan-pernyataan yang diungkapkan oleh Menteri Susi, beliau menyatakan "Jangan sampai laut kita yang besarnya $70 \%$ atau 5 kali lebih besar laut kita dari Thailand, dan beribu-ribu kali lipat dengan Malaysia tetapi angka ekspor kita kalah jauh dibandingkan Malaysia dan Thailand". Pernyataan tersebut membingkai bahwa illegal fishing menyebabkan kerugian yang besar bagi Indonesia di sektor ekonomi. Hal tersebut menyebabkan Indonesia tertinggal dari negara-negara tetangganya di ASEAN.

Referent object yang ditujukan di speech act yang dilakukan adalah negara. Agenda pemberantasan IUUF diletakkan dalam sub-tema besar 'Kedaulatan' dalam laman web Kementerian Kelautan dan Perikanan. Hal tersebut menunjukkan bahwa maraknya aktivitas IUUF merupakan ancaman bagi kedaulatan negara sebagai referent object. Selain itu, speech act tersebut membingkai kerugian yang disebabkan aktivitasi illegal fishing sebagai tanggungjawab Indonesia. Menteri Susi, dalam speech act-nya, memposisikan Indonesia berada dalam kompetisi dengan negara-negara lain, seperti Malaysia, Thailand, sehingga kegagalan menangani isu penangkapan ikan illegal dapat membuat Indonesia kalah dalam struktur kompetisi tersebut. Berdasarkan pemaparan di atas, dapat penulis simpulkan bahwa sekuritisasi IUUF oleh pemerintah Indonesia berada di sektor ekonomi dan dengan ekonomi nasional sebagai referent object.

\section{Faktor-faktor Keberhasilan Sekuritisasi}

Kesuksesan suatu securitizing move dapat diatribusikan pada kondisi-kondisi yang mendukung (facilitating condition). Penulis mencoba menjabarkan kondisi-kondisi dalam upaya sekuritisasi aktivitas IUUF sebagai berikut (1) internal, melalui penggunaan tata bahasa dan struktur linguistik-nya; dan (2) eksternal, yang mencakup modal sosial dari aktor yang mensekuritisasi serta fitur dari ancaman yang disekuritisasi (Buzan et. al. 1998).

Pertama adalah faktor internal. Berdasarkan pemaparan dari Kementrian Kelautan dan Perikanan (KKP) maupun Menteri Susi 
Pudjiastuti, keduanya melakukan speech act untuk melakukan sekuritisasi isu IUUF. Di laman KKP misalnya, disebutkan bahwa kerugian Indonesia dari aktivitas IUUF cukup besar sehingga dapat mengganggu 'stabilitas politik'. Kata-kata 'stabilitas politik' dapat penulis interpretasikan sebagai upaya untuk memberikan label terhadap suatu isu sebagai hal yang penting karena kata-kata tersebut menyimpan makna yang mendesak. Isu IUUF disajikan seakan-akan menjadi suatu ancaman eksistensial bagi masyarakat Indonesia. Selain itu, dalam memaparkan isu tersebut, Menteri Susi menggunakan kata-kata 'musuh negara' dan 'musuh dunia'. Katakata Menteri Susi seakan membingkai para pelaku penangkapan ilegal sebagai aktor yang menjadi ancaman eksistensial di level yang tinggi.

Kedua adalah faktor eksternal. Aktor yang melakukan sekuritisasi di isu tersebut adalah Kementerian Kelautan dan Perikanan, terutama melalui Menteri Kelautan dan Perikanan, Susi Pudjiastuti. Modal sosial Menteri Susi Pudjiastuti membantu sebagai faktor pendukung keberhasilan sekuritisasi isu tersebut. Sebelum diangkat menjadi Menteri di Era Presiden Joko Widodo, Susi Pudjiastuti dikenal sebagai pengusaha pengekspor ikan (Tirto.id n.d.). Modal sosial sebagai pengusaha di sektor perikanan membuat speech act yang dilakukan lebih mendapatkan sorotan dari masyarakat Indonesia secara umum dan para nelayan secara khusus. Dengan modal tersebut, speech act yang dilakukan Menteri Susi Pudjiastuti mendapatkan legitimasi sehingga dengan mudah membuat isu IUUF diterima sebagai isu keamanan.

Illegal Fishing mempunyai fitur yang nyata sehingga dapat dengan mudah dilakukan sekuritisasi. Kapal-kapal yang melewati batasbatas perairan Indonesia dapat dilihat dan dampaknya dirasakan secara nyata oleh para nelayan Indonesia. Akibatnya, jumlah nelayan di Indonesia pun turun selama sepuluh tahun terakhir. Berdasarkan data dari Kementerian Kelautan dan Perikanan, jumlah nelayan pada tahun 2003 berjumlah 1,6 juta dan pada tahun 2013, jumlah nelayan menurun menjadi sekitar delapan ratus ribu jiwa (Chandra 2016). 


\section{Simpulan}

Berdasarkan uraian di atas, penulis menyimpulkan bahwa dalam menanggapi maraknya kegiatan IUUF di perairan Indonesia, pemerintah Indonesia telah melakukan upaya sekuritisasi isu. Speech act telah disampaikan oleh securitizing actor, yakni pemerintah Indonesia dan Kementerian Kelautan dan Perikanan melalui laman situs resmi mereka, serta melalui berbagai pidato Menteri KKP, Susi Pudjiastuti. Speech act yang dilakukan oleh pejabat pemerintah Indonesia tersebut bertujuan untuk mendorong masyarakat Indonesia untuk memberikan kewenangan bagi pemerintah untuk melakukan kebijakan publik yang sesuai demi menangani illegal fishing. Speech act tersebut mendapat respons positif dari masyarakat Indonesia, terutama para nelayan. Isu IUUF berhasil diangkat menjadi isu keamanan sehingga pemerintah dapat menggunakan metode diluar kebiasaan dalam menangani isu tersebut. Pemerintah Indonesia melakukan penenggelaman kapal-kapal yang melakukan penangkapan ikan ilegal di perairan Indonesia, serta telah membentuk Satgas 115 sebagai salah satu cara untuk menangani isu IUUF. Keberhasilan securitizing move dalam kasus ini dapat diatribusikan pada faktor facilitating condition, baik secara internal maupun eksternal. Kalimat dalam speech act mengandung kata yang menunjukkan urgensi dalam menanganinya, terlebih karena speech act ini disampaikan oleh Kementerian Kelautan dan Perikanan sehingga mempunyai legitimasi yang tinggi di mata masyarakat. Selain itu, masyarakat juga telah merasakan dampak buruk kegiatan IUUF sehingga mempermudah proses sekuritisasi. 


\section{Daftar Pustaka}

\section{Buku}

Buzan, Barry, Ole Waever, and Jaap de Wilde. 1998. Security: A New Framework of Analysis. Boulder: Lynne Rienner.

Walt, Stephen. 2015. In International Security Studies: Theory and Practice, by Peter Hough, Shahin Malik, Andrew Moran and Bruce Pilbeam, 6. New York: Routledge.

\section{Jurnal Ilmiah}

Buzan, Barry. 1997. "Rethinking Security After the Cold War." Cooperation and Conflict 5-28.

Floyd, Ryta. 2016. "Extraordinary or ordonary emergency measures: what and who defines the 'success' of securitization?" Cambridge Review of International Affairs 677-694.

\section{Internet}

Burhani, Ruslan. 2015. "Susi: “Illegal Fishing" musuh dunia." Antara News. Januari 09. Accessed Oktober 10, 2017. http://www. antaranews.com/berita/473225/susi-illegal-fishing-musuhdunia.

Chandra, Ardan Adhi. 2016. "Gara-gara Illegal Fishing, Jumlah Nelayan RI Turun." detikFinance. Agustus 01. Accessed Oktober 12, 2017. https://finance.detik.com/berita-ekonomibisnis/3265799/gara-gara-illegal-fishing-jumlah-nelayan-riturun.

detikFinance. 2014. “2007-2012, RI Sudah Tenggelamkan 38 Kapal Asing Ilegal." detikFinance. Desember 04. Accessed Juni 09, 2017. http:/ / finance.detik.com/berita-ekonomi-bisnis/2767817/.

-. 2014. “Ini Pidato Lengkap Susi yang Bikin Ribuan Undangan Setijab Tepuk Tengan Meriah." detikFinance. Oktober 29. Accessed Juni 09, 2017. https://finance.detik.com/ekonomibisnis/2733134/ini-pidato-lengkap-susi-yang-bikin-ribuanundangan-sertijab-tepuk-tangan-meriah.

DH, Agung. 2016. "Susi Telah Tenggelamkan 151 Kapal Pencuri Ikan." Tirto.id. Februari 22. Accessed Juni 09, 2017. https://tirto. id/susi-telah-tenggelamkan-151-kapal-pencuri-ikan-ED.

Indra, Putu Agung Nara. 2016. “Tenggelamkan Kapal Lagi, Bu 
Susi?" Tirto.id. Agustus 04. Accessed Juni 09, 2017. https://tirto. id/tenggelamkan-kapal-lagi-bu-susi-bw5E.

KKP News. 2016. "Cegah Illegal Fishing Indonesia-Australia Patroli Bersama di Perbatasan." KKP News. November 04. Accessed Oktober 10, 2017. http://news.kkp.go.id/index.php/ cegah-illegal-fishing-indonesia-australia-patroli-bersama-diperbatasan/.

-. 2017. "Indonesia - Norwegia Bersinergi Perangi Praktik Illegal Fishing." KKP News. Juni 08. Accessed Oktober 10, 2017. http:// news.kkp.go.id/index.php/indonesia-norwegia-bersinergiperangi-praktik-illegal-fishing/.

-. 2016. "RI - Rusia Sepakati Kerja Sama Berantas Illegal Fishing." KKP News. Mei 19. Accessed Oktober 10, 2017. http://news. kkp.go.id/index.php/ri-rusia-sepakati-kerja-sama-berantasillegal-fishing/.

-. 2015. "Sumpah adat nelayan cegah Illegal Fishing." KKP News. Oktober 16. Accessed Oktober 10, 2017. http://news.kkp.go.id/ index.php/sumpah-adat-nelayan-cegah-illegal-fishing/.

-. 2015. “Tanpa Peran Masyarakat dan Media, Menteri Susi: Kami Tidak Bisa Berantas Illegal Fishing." KKP News. November 22. Accessed Oktober 10, 2017. http://news.kkp.go.id/index.php/ tanpa-peran-masyarakat-dan-media-menteri-susi-kami-tidakbisa-berantas-illegal-fishing/.

Marta, Muhammad Fajar. 2017. “Susi dan Tiga Pilar yang TakSekadar Mitos`." Kompas. September 07. Accessed Oktober 10, 2017. http://ekonomi.kompas.com/read/2017/09/07/051546726/ susi-dan-tiga-pilar-yang-tak-sekadar-mitos.

Movanita, Ambaranie Nadia Kemala. 2016. “Menteri Susi: Saya Beruntung Punya Presiden yang Mendukung Penuh Pemberantasan "Illegal Fishing"." Kompas. November 09. Accessed Oktober 10, 2017. http://nasional.kompas.com/ read/2016/11/09/12495771/menteri.susi.saya.beruntung. punya.presiden.yang.mendukung.penuh.pemberantasan. illegal.fishing.

Pasopati, Giras. 2015. “Setahun jadi Menteri, Susi Tenggelamkan Kapal Tanpa Diadili." CNN Indonesia. Oktober 20. Accessed Juni 09, 2017. http://www.cnnindonesia.com/ ekonomi/20151020121906-92-86037/setahun-jadi-menteri-susitenggelamkan-kapal-tanpa-diadili/. 
Samantha, Gloria. 2013. “Terbaru: Panjang Garis Pantai Indonesia Capai 99.000 Kilometer." National Geographic. Oktober 21. Accessed Juni 09, 2017. http://nationalgeographic.co.id/ berita/2013/10/terbaru-panjang-garis-pantai-indonesia-capai99000-kilometer

Tirto.id. n.d. "Susi Pudjiastuti." Tirto.id. Accessed Oktober 15, 2017. https://tirto.id/m/susi-pudjiastuti-fw.

Wardani, Marisa Dwi Kusuma. 2017. “RI - Sri Lanka Sepakati Kerja Sama Berantas Illegal Fishing dan Kelola Perikanan Berkelanjutan." News KKP. Maret 08. Accessed Oktober 10, 2017. http://news.kkp.go.id/index.php/ri-sri-lanka-sepakatikerja-sama-berantas-illegal-fishing-dan-kelola-perikananberkelanjutan/.

Wiji, Nurhayat. 2017. “Susi Minta Penegakan Illegal Fishing Tahun ini Lebih Tegas." Kumparan. Januari 20. Accessed Juni 09, 2017. https://kumparan.com/wiji-nurhayat/susi-minta-penegakanillegal-fishing-tahun-ini-lebih-tegas.

Winata, Rozie. 2015. "Pemberantasan Illegal Fishing Belum Maksimal, HNSI Dukung Perpres IUU Fishing." KKP News. Oktober 05. Accessed Oktober 10, 2017. http://news.kkp.go.id/ index.php/pemberantasan-illegal-fishing-belum-maksimalhnsi-dukung-perpres-iuu-fishing/. 